American J. of Engineering and Applied Sciences 2 (3): 526-536, 2009

ISSN 1941-7020

(C) 2009 Science Publications

\title{
Engineering of Ground for Liquefaction Mitigation Using Granular Columnar Inclusions: Recent Developments
}

\author{
${ }^{1}$ A. Murali Krishna and ${ }^{2}$ M.R. Madhav \\ ${ }^{1}$ Indian Institute of Technology Guwahati, Guwahati 781 039, India \\ ${ }^{2}$ Jawaharlal Nehru Technological University, Hyderabad 500 085, India
}

\begin{abstract}
Problem statement: Liquefaction was the most hazardous damage during an earthquake. Ground improvement techniques were employed to mitigate liquefaction hazards. Most common methods to improve engineering properties of soils are densification, reinforcement, grouting/mixing and drainage. Among various remedial measures available, installation of columnar granular inclusions is the most widely adopted method for liquefaction mitigation. Approach: Columnar granular inclusions function as drains and permit rapid dissipation of earthquake induced pore pressures by virtue of their high permeability. Results: One of the chief benefits of ground treatment with granular piles is the densification of in situ ground by which the in-situ properties of the ground get modified to mitigate liquefaction potential. Further, the very high deformation modulus and stiffness of the granular pile material provide reinforcement for the in situ soil and offer another mechanism to mitigate liquefaction. The study described briefly the phenomenon of liquefaction and the associated features. A short discussion on various ground improvement methods available for liquefaction mitigation was presented highlighting the importance of columnar inclusions. Construction methods of different granular columnar inclusions like sand compaction piles/ granular piles were discussed briefly. Recent developments in the research of columnar granular inclusions as liquefaction counter measures were presented in relation to physical, numerical and analytical model studies. Conclusion/Recommendations: Columnar granular inclusions were demonstrated to be very effective for liquefaction mitigation in different case studies and research investigations.
\end{abstract}

Key words: Liquefaction, mitigation, columnar inclusions, granular piles, stone columns, analytical/numerical studies

\section{INTRODUCTION}

Liquefaction and its associated ground displacements resulting from earthquake shaking are the major cause of damage in loose saturated granular soils. Many liquefaction induced failures or nearfailures of foundations, buildings and infrastructure facilities like highway/railway embankments, port facilities and earth dams have been reported across the globe during various earthquakes. The 1995-Kobe earthquake emphasized the importance of foundation liquefaction as a potential source of damage. Liquefaction can be manifested either by the formation of boils and mud-spouts at the ground surface, by seepage of water through ground cracks or in some cases by the development of quicksand conditions over substantial areas ${ }^{[1]}$.

Ground improvement techniques like densification, reinforcement, grouting/mixing and drainage are commonly employed to mitigate liquefaction hazards. Provision of columnar granular inclusions like gravel drains/granular piles/stone columns is the most commonly adopted ground treatment methodology for liquefaction mitigation which has proved its effectiveness in many instances ${ }^{[2]}$. Granular piles are the most widely preferred alternative all over the world, due to technical feasibility, low energy utilization and cost effectiveness. They improve the ground by reinforcement and densification of the surrounding soil apart from providing drainage. Different mechanisms operate in the function of gravel drains/granular piles in liquefaction mitigation. These mechanisms can be stated as drainage, storage, dilation, densification and reinforcement.

Ground improvement by means of granular piles/stone columns/geopiers, which is associated with partial substitution of the in situ soil, originated in the sixties. Stone columns generally use gravel or crushed

Corresponding Author: A. Murali Krishna, Department of Civil Engineering, Indian Institute of Technology Guwahati, Guwahati 781039, India Tel: (91-361) 2582429 Fax : (91-361) 2582440 
stone as backfill. Effect of method of installation, cased and uncased holes, number of lifts and magnitude of compactive energy per lift given to granular piles and pile spacing were discussed by Madhav and Thiruselvam ${ }^{[3]}$. Consideration of granular piles/drains installation as a possible method of stabilizing a soil deposit, susceptible to liquefaction, started with the work by Seed and Booker ${ }^{[4]}$. They state that pore-water pressures generated by cyclic loading get dissipated almost as fast as they are generated through the system of gravel or rock drains. Since then, different types of columnar inclusions are used as liquefaction remedial measure, which basically provide the drainage facility to dissipate the excess porewater pressures during cyclic loading almost as fast as they generated.

This study presents some of the recent developments in this very vital area of liquefaction and its counter-measures highlighting the importance of columnar granular inclusions.

Liquefaction and counter measures: Liquefaction is the state when saturated sandy soil looses its shear strength due to increased pore pressure and consequent reduction in effective stresses. Terzaghi ${ }^{[5]}$ originally introduced the term liquefaction into the engineering community in the classical book Erdbaumechanik ${ }^{[6]}$ and Casagrande $^{[7]}$, in 1936, used the term to explain the massive soil failures at Fort Peck Dam. The concept of liquefaction gathered worldwide attention in the 1960's, when in 1964 large magnitude earthquakes located near Anchorage, Alaska and Niigata, Japan caused massive structural damage through ground failure. Significant amount of work on this topic has been performed in the last few decades since these earthquakes, resulting in several state-of-the-art papers relating to the study, evaluation and remediation of liquefaction ${ }^{[8-19]}$.

As a consequence of the applied cyclic stresses, the structure of the cohesionless soil tends to become more compact but with a resulting transfer of stresses to the porewater and a reduction in the effective stresses on the soil grains. As a result, the soil grain structure rebounds to the extent required to keep the volume constant and this interplay of volume reduction and soil structure rebound determines the magnitude of the increase in porewater pressure in the soil ${ }^{[10]}$. The basic phenomenon is illustrated (Fig. 1) schematically by Seed ${ }^{[11]}$. The mechanism can be quantified so that the pore pressure increases due to any given sequence of stress applications can be computed from knowledge of the stress-strain and the volume change characteristics of the sand under cyclic strain conditions and the rebound characteristics of the sand due to stress reduction. Relationships between cyclic stress ratio and pore pressure ratio, number of cycles required to cause liquefaction and critical stress ratio with relative density were presented by Seed et al. ${ }^{[20]}$ based on the study on porewater pressure changes during soil liquefaction. The effect of seismic history on liquefaction characteristics of saturated sands was studied by ${ }^{[2]]}$ with a concluding remark that the deposits of sand subjected to low magnitude earthquakes, which were not sufficiently strong to cause liquefaction, will develop an increased resistance to liquefaction in subsequent earthquakes even though, there may not be a significant change in density. Seed ${ }^{[11]}$ developed a method to estimate liquefaction potential for sand under level ground conditions using standard penetration test data. This method was based on field performance data from sites, which either had or had not experienced liquefaction due to earthquake loading. Similar such research works on the liquefaction and its evaluation are extensively reviewed and presented $^{[14,15]}$. The recent review on this very interesting topic is the work by Sawicki and Mierczynski ${ }^{[18]}$, wherein the authors reviewed historical developments of mechanics of saturated granular soils in relation to the liquefaction phenomenon, development of theoretical approaches to liquefaction-related problems and modeling. In the recent years studies on the micro mechanical behavior of granular assemblies, in relation to liquefaction and associated mechanisms, are carried by

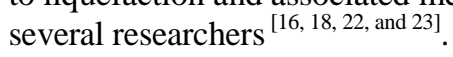

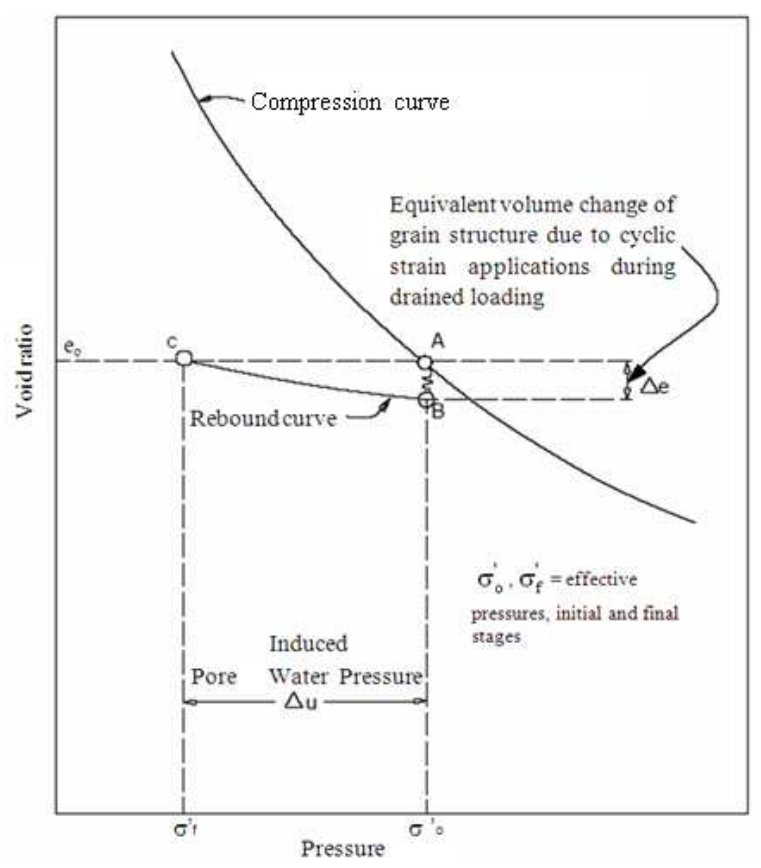

Fig. 1:Schematic illustration of mechanism of pore pressure generation during cyclic loading ${ }^{[11]}$ 
Am. J. Engg. \& Applied Sci., 2 (3): 526-536, 2009

Table 1: Various ground improvement methods and their locations considered by Mitchell and Wentz ${ }^{[2]}$

\begin{tabular}{llllll}
\hline Sr. No. & Name & Location & Soil conditions & Method & Year of treatment \\
\hline 1 & Medical/dental clinic & Treasure Island & Hydraulic sand fill & Stone columns & 1989 \\
2 & Office building No. 450 & Treasure Island & Hydraulic sand fill & Sand compaction piles & 1967 \\
3 & Facilities 487-489 & Treasure Island & Hydraulic sand fill & Vibrocompactin & 1972 \\
4 & Approach area, pier 1 & Treasure Island & Hydraulic sand fill & Stone columns & 1984 \\
5 & Building 453 & Treasure Island & Hydraulic sand fill & Non-structural timber piles & 1969 \\
6 & Esplanade extension & Richmond & Silty, sandy & Stone columns & 1986 \\
& East shore, marina bay & & and gravelly fill & & 1981 \\
7 & East bay park condominiums & Emeryville & Silty sand fill & Vibrocompactin & 1985 \\
8 & Harbor bay business park & Alameda & Hydraulic sand fill & Deep dynamic compactin & 1988 \\
9 & Hanover properties & Union city & Silty sand fill & Deep dynamic compactin & 1978 \\
10 & Kaiser hospital & South San Francisco & Hydraulic sand fill & Compaction grout & 1986 \\
11 & Riverside avenue bridge & Santa Cruz & Sands and gravels & Chemical Grout & 1978 \\
12 & Adult detention facility & Santa Cruz & Silty, sandy fill & Deep dynamic compactin & \\
\hline
\end{tabular}

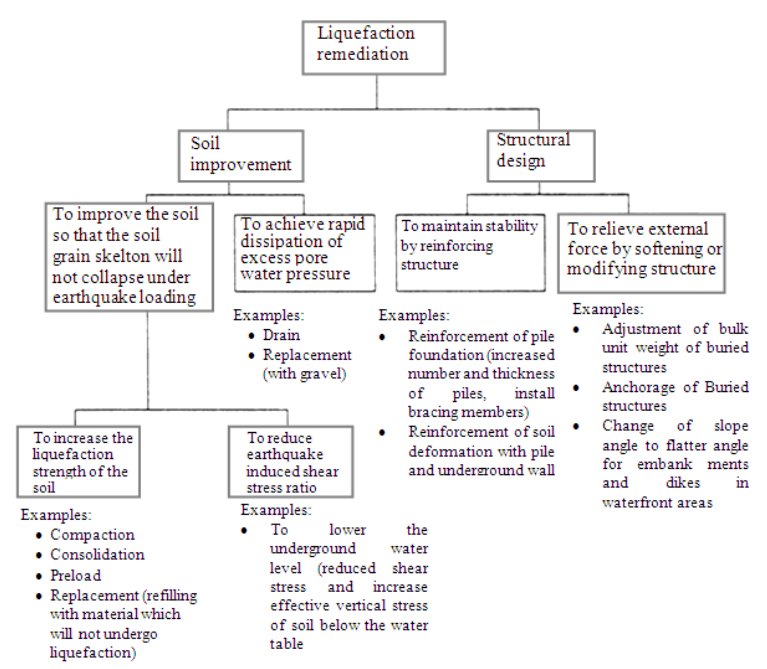

Fig. 2 Strategy for liquefaction remediation ${ }^{[25]}$

Various ground improvement methods that can be used as liquefaction counter measures can be classified into two broad categories ${ }^{[24]}$ : (i) Prevention of liquefaction and (ii) Reduce the damage to structures due to liquefaction. The former one can be achieved by increasing the undrained cyclic strength as well as by improving the resistance to deformation or by dissipation of pore water pressure. The second one, reducing the damage, could be attained by strengthening the foundation of the structures and the ground supporting the structures to avoid reduction in bearing capacity or making the structures more flexible so that it can deform in accordance with the ground movement in case of buried structures ${ }^{[24]}$. Resistance to liquefaction can be improved by increasing the density, modifying the grain size distribution, stabilizing the soil fabric, reducing the degree of saturation, dissipation of the excess pore pressures generated and intercepting the propagation of excess pore pressures. PHRI ${ }^{[25]}$ summarize (Fig. 2) the basic strategies for liquefaction remediation.

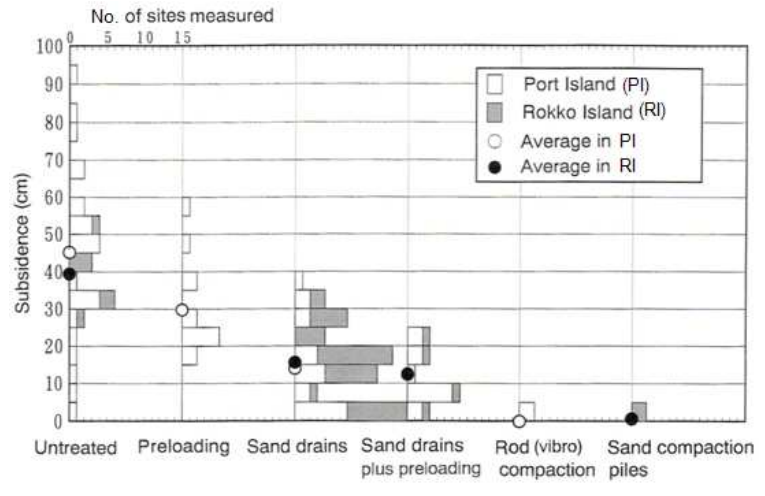

Fig. 3: Comparison of ground subsidence in zones treated with different methods ${ }^{[26]}$

The 1989 Loma Prieta earthquake experience provided the first opportunity to evaluate the behavior of treated ground that has been actually subjected to significant seismic shaking ${ }^{[2]}$. Twelve sites treated with different improvement methods prior to the earthquake were evaluated comprehensively by Mitchell and Wentz $^{[2]}$ (Table 1). They conclude that the procedures used for prediction of liquefaction were reliable and the ground improvement was very effective in mitigating liquefaction. Provision of gravel drains/granular piles/stone columns was the most commonly adopted ground treatment methodology for liquefaction mitigation which has proved its effectiveness in many instances.

Yasuda et al. ${ }^{[26]}$ investigated the liquefied and notliquefied subsoil conditions of two reclaimed islands in Kobe City after the 1995 Hyogoken-Nambu earthquake. Based on the study it was found that the non-liquefied zones had been improved by several methods, including sand compaction piles, rod (vibro) compaction, sand drains and preloading, before buildings had been constructed on them. Figure 3 depicts performance of different ground improvement methods in reducing the ground subsidence in the earthquake affected sites. 

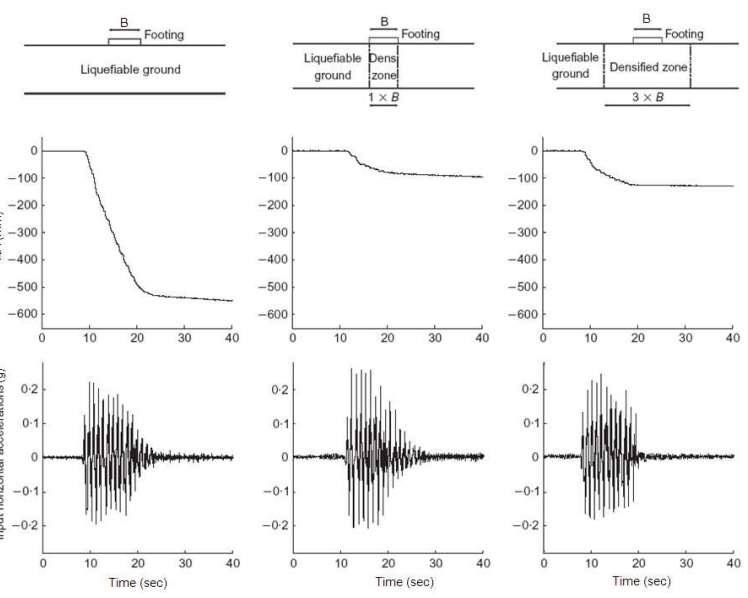

Fig. 4: Liquefaction-induced settlement of a bridge pier built with different in-situ densification widths $^{[27]}$

It can be observed that the subsoil treated with columnar inclusions like sand compaction piles did not liquefy and nor subside even though the earthquake shaking was very strong. Madabhushi ${ }^{[27]}$ discussed and showed the effectiveness of three different ground improvement methods, viz., in-situ densification, gravel drains and grouting, through dynamic centrifugal model tests. Figure 4 evidences the effectiveness of in situ densification and its extent.

Among the different ground improvement methods available, provision of columnar granular inclusions in the in-situ soil is considered to be the most effective method for liquefaction mitigation due to its ability to provide drainage facility in lowering the excess porewater pressures and strengthen the ground.

\section{MATERIALS AND METHODS}

Columnar granular inclusions as liquefaction counter-measure: Columnar inclusions are of different types viz. sand drains, sand compaction piles; prefabricated vertical drains, granular piles or stone columns and lime or cement columns which are stiffer and stronger that the ambient soil, that can be installed in different arrays as shown in the Fig. 5. Installation of sand compaction piles in dynamic vibratory and static methods was discussed by Tsukamoto et al. ${ }^{[28]}$ (Fig. 6). Theoretical background, analysis, design aspects and installation techniques for stone columns/granular piles were being developed since 1970 s by various researchers and practitioners ${ }^{[2-34]}$. Granular piles are installed by vibro-compaction, vibro-replacement, cased borehole (rammed stone columns/rammed granular piles) or by simple auger methods ${ }^{[31,35]}$.

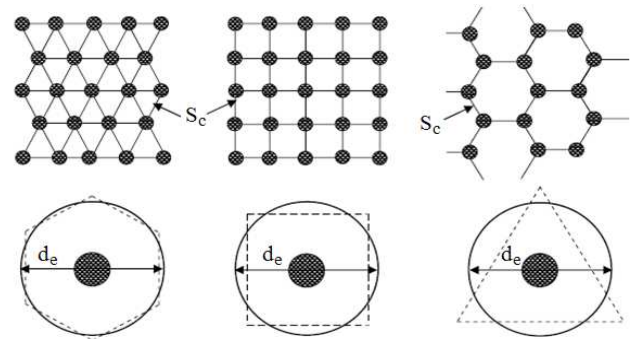

Fig. 5: Various arrangements of columnar inclusions and zones of influence; (a): Triangular; (b): Square; (c): Hexagonal

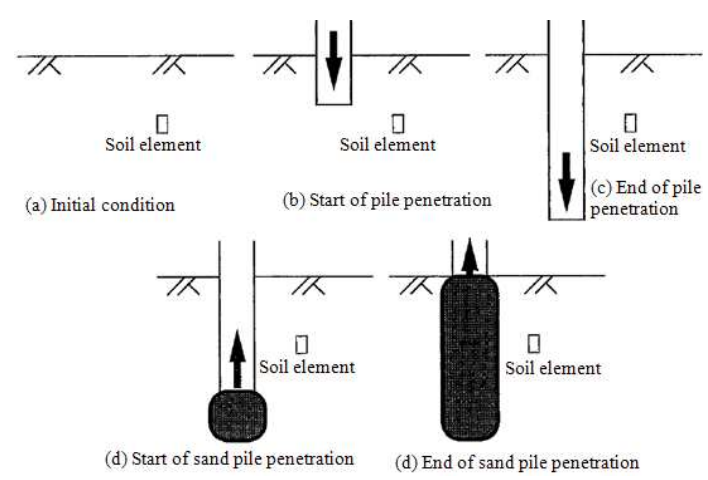

Fig. 6: Installation of sand compaction piles ${ }^{[28]}$

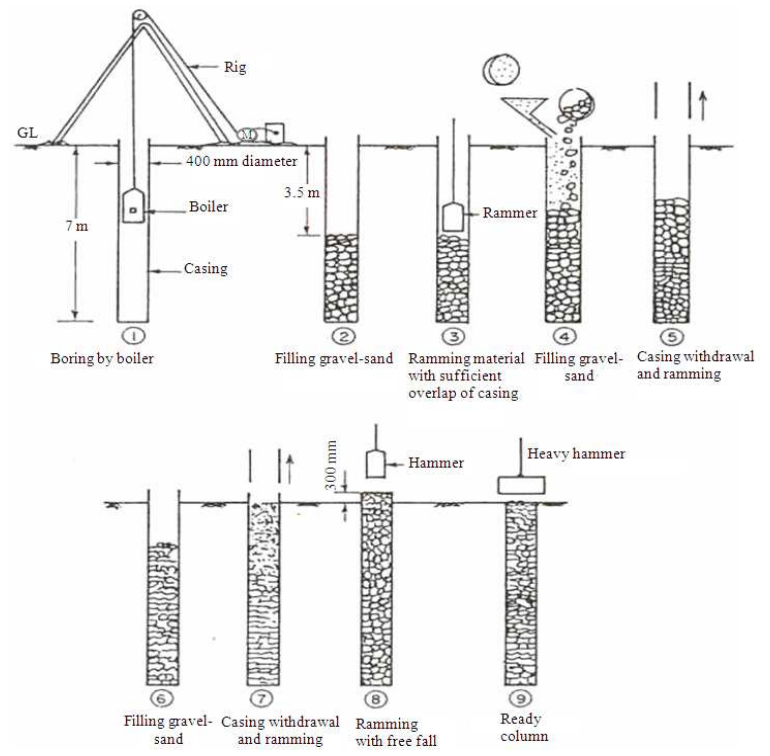

Fig. 7: Installation of stone columns-cased borehole method $^{[36]}$

In cased borehole method ${ }^{[36]}$, granular piles are installed into the ground by full displacement methods and by ramming in stages, using a heavy falling weight, within a 'pre-bored casing' or 'driven closed end casing' and retracting the casing pipe stepwise (Fig. 7). In recent 
years, use of encased columns as a ground improvement method is increasing. Granular inclusions are encapsulated in geosynthetic materials to increase the resistance to bulging ${ }^{[37-42]}$.

The pioneering work on gravel drains as a possible method to stabilize liquefaction susceptible soil deposit is reported by Seed and Booker ${ }^{[4]}$. Numerous publications $^{[43-47]}$ describe the use of stone columns for ground reinforcement and their potential to mitigate liquefaction.

Granular columnar inclusions (Granular piles) help in mitigating earthquake induced liquefaction effects through one or more of these functions or effects:

- Granular piles function as drains and permit rapid dissipation of earthquake induced pore pressures by virtue of their high permeability with the additional advantage that they tend to dilate as they get sheared during an earthquake event

- $\quad$ Pore water pressures generated by cyclic loading get dissipated almost as fast as they are generated due to significant reduction in the drainage path

- Granular piles density and reinforce the in-situ soil; improve the deformation properties of the ambient soil

- Granular piles, installed in to a very dense state, are not prone to liquefaction and replace a significant quantity of in-situ liquefiable soil

- Granular piles modify the nature of earthquake experienced by the in situ soil

\section{RESULTS}

Adalier and Elgamal ${ }^{[48]}$ reviewed the current state of stone column technologies as a liquefaction countermeasure. Sasaki and Tinaguchi ${ }^{[49]}$ conducted large scale shaking table test on gravel drain system as a liquefaction counter-measure. Figure 8 shows different model configurations considered and typical distribution of the pore water pressures ${ }^{[49]}$. Adalier et al. ${ }^{[50]}$ performed a series of highly instrumented dynamic centrifuge model tests (Fig. 9) to evaluate effectiveness of stone columns in mitigating the liquefaction potential of non-plastic silty deposits. Al-Homoud and Degen ${ }^{[47]}$ present an introduction to earthquake-resistant design of marine stone columns. Similar studies on different types of granular columnar inclusions include ${ }^{[51,28,52]}$ on sand compaction piles $^{[53]}$ on prefabricated vertical drains ${ }^{[27,54,55]}$ on gravel drains.

Analytical studies on columnar inclusions as liquefaction remedial measure: Seed and Booker ${ }^{[4]}$ were the first to propose an analytical model for the generation and dissipation of pore pressure in a soil

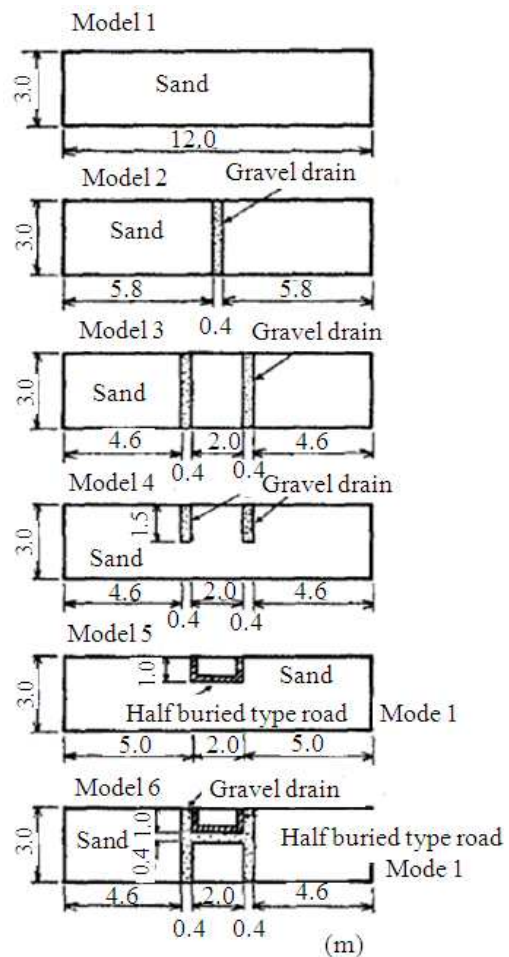

(a)

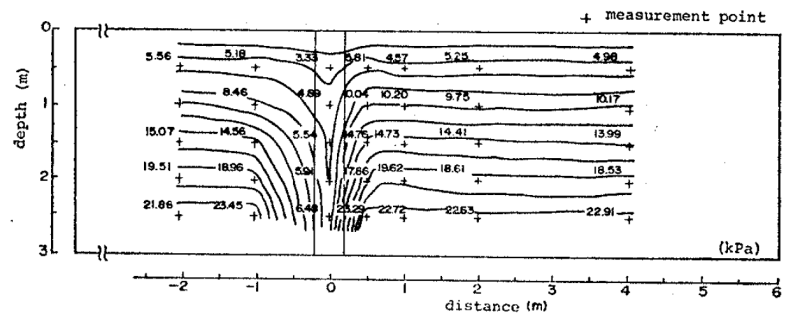

(b)

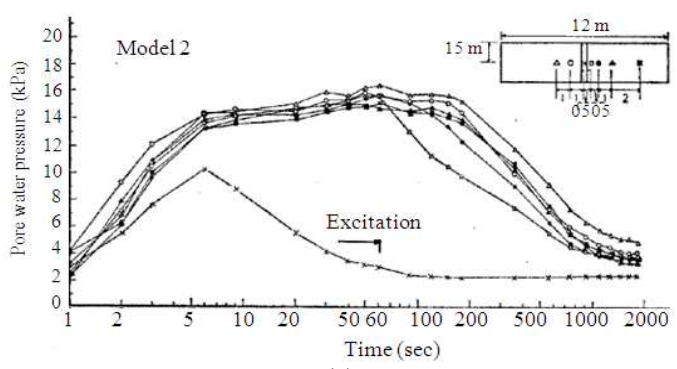

(c)

Fig. 8: (a): Different models used; (b): Distribution of pore-water pressure for model 2 after $20 \mathrm{sec}$; (c): Variation of generation and dissipation of pore water pressures for model $2^{[49]}$

deposit with vertical drains. Under the assumptions of purely radial drainage, constant coefficient of compressibility and infinite permeability of drains, 


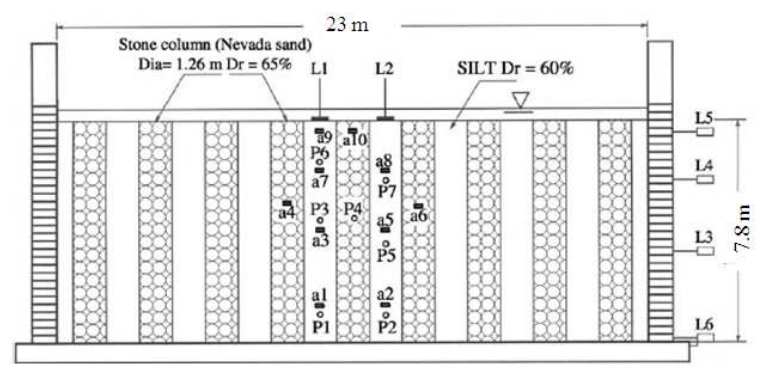

Fig. 9: Typical model configuration considered for centrifugal model studies ${ }^{[50]}$

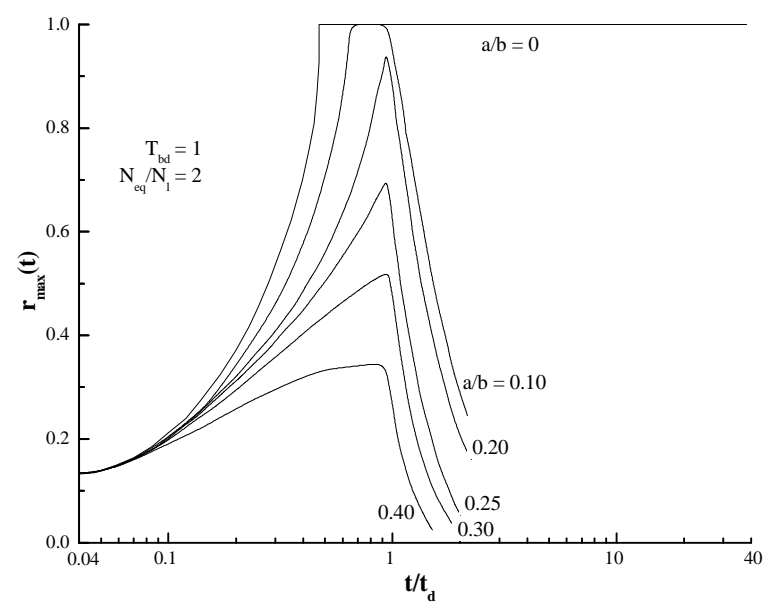

Fig. 10: Effect of drain diameter and drain spacing on maximum pore pressure ratio ${ }^{[4]}$

design charts (Fig. 10) were developed to evaluate the effects of drain diameter and spacing for the expected earthquake loading on excess pore pressure ratio. For flow into a gravel drain, assuming pure radial flow and constant coefficients of permeability $\left(\mathrm{k}_{\mathrm{h}}\right)$ and volume compressibility $\left(\mathrm{m}_{\mathrm{v}}\right)$, the governing equation can be written as ${ }^{[4]}$ :

$$
\frac{k_{h}}{\gamma_{W} \cdot m_{v}}\left(\frac{1}{r} \frac{\partial u}{\partial r}+\frac{\partial^{2} u}{\partial r^{2}}\right)=\frac{\partial u}{\partial t}-\frac{\partial u_{g}}{\partial N} \cdot \frac{\partial N}{\partial t}
$$

Where:

$\mathrm{u}=$ The excess pore pressure at a radial distance, $\mathrm{r}$, from the centre

$\mathrm{t}=$ Time, $\gamma_{\mathrm{w}}$ - the unit weight of water

$\mathrm{u}_{\mathrm{g}}=$ Peak excess hydrostatic porewater pressure generated by the earthquake

The rate of generation of pore pressure during an earthquake event is defined by: $\frac{\partial \mathrm{u}_{\mathrm{g}}}{\partial \mathrm{N}}=\frac{\sigma^{\prime}}{\mathrm{a}^{\mathrm{N} \mathrm{N}_{1}}} \frac{1}{\operatorname{Sin}^{2 \mathrm{a}-1}\left(\frac{\pi}{2} \mathrm{r}_{\mathrm{u}}\right) \cos \left(\frac{\pi}{2} \mathrm{r}_{\mathrm{u}}\right)}$

Where:

$\mathrm{r}_{\mathrm{u}}=\mathrm{u} / \sigma_{\mathrm{o}}^{\prime}=$ The pore pressure ratio

$\sigma_{0}^{\prime} \quad=$ The initial mean bulk effective stress for axi-symmetric conditions or the initial vertical effective stress for simple shear conditions

$\mathrm{N}_{\mathrm{l}} \quad=$ The number of cycles required to cause liquefaction

$\alpha \quad=$ An empirical constant which is a function of the soil properties with a typical average value of 0.7

The irregular cyclic loading induced by an earthquake is converted ${ }^{[56]}$ to an equivalent number, $\mathrm{N}_{\mathrm{eq}}$, of uniform cycles at an amplitude of $65 \%$ of the peak cyclic shear stress, i.e., $\tau_{\mathrm{cyc}}=0.65 \tau_{\max }$, occurring over a duration of time, $t_{d}$ and:

$\frac{\partial N}{\partial t}=\frac{N_{e q}}{t_{d}}$

Tokimatsu and Yoshimi ${ }^{[57]}$, Sasaki and Taniguchi ${ }^{[49]}$ and Onoue ${ }^{[58]}$, report results similar to those of Seed and Booker $^{[4]}$ taking into consideration additional factors such as well resistance (finite permeability of gravel drain) and drain slenderness ratio (slenderness ratio: $\mathrm{L} / \mathrm{r}$, where $\mathrm{L}$ is the length and $\mathrm{r}$ the radius of the gravel drain). Pestana et al. ${ }^{[59,60]}$ analyzed the provision of a reservoir to minimize the drain resistance to flow in to the drain. Poorooshasb et al. ${ }^{[61]}$ propose an equivalent coefficient permeability, $\mathrm{k}_{\mathrm{eq}}=\mathrm{k}_{\mathrm{untr}} \cdot \mathrm{t}_{50}$ (for untreated ground) $/ \mathrm{t}_{50}$ (for treated ground), for the treated soil, in terms of the permeability, $k_{\text {untr }}$, of untreated ground and $t_{50}$ values for the untreated and granular pile treated ground are the times for $50 \%$ degree of consolidation based on one dimensional and radial consolidation theories respectively. Dilation effect on the drainage function of granular piles was studied by Madhav and Arlekar ${ }^{[62]}$. The densification effect of granular piles in improving deformation properties of the ambient soil was studied by Murali Krishna and Madhav ${ }^{[63]}$ and Murali Krishna et al. ${ }^{[64,65]}$.

Murali Krishna et al. ${ }^{[64]}$ incorporated the densification effect of granular piles, with respect to variation of flow parameters from the centre of the granular pile, in the analysis of pore pressure generation and dissipation that was originally developed by ${ }^{[4]}$. 
Am. J. Engg. \& Applied Sci., 2 (3): 526-536, 2009

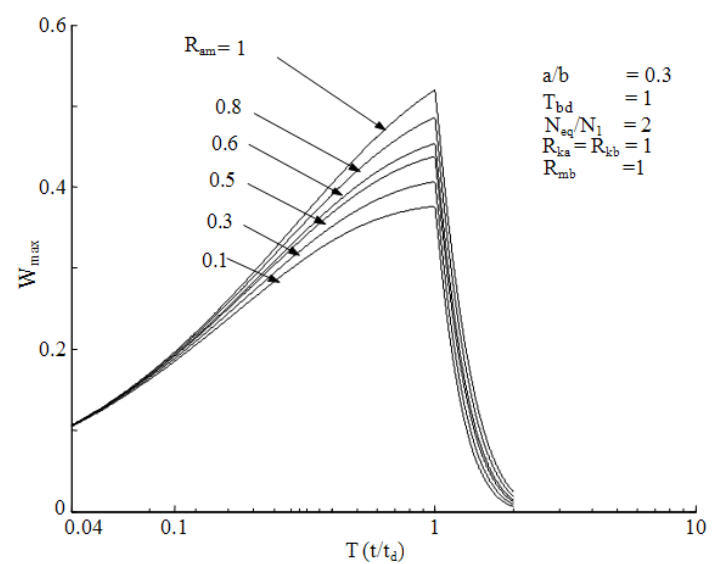

Fig. 11: Effect of $\mathrm{R}_{\operatorname{ma}}$ on $\mathrm{W}_{\max }{ }^{[64]}$

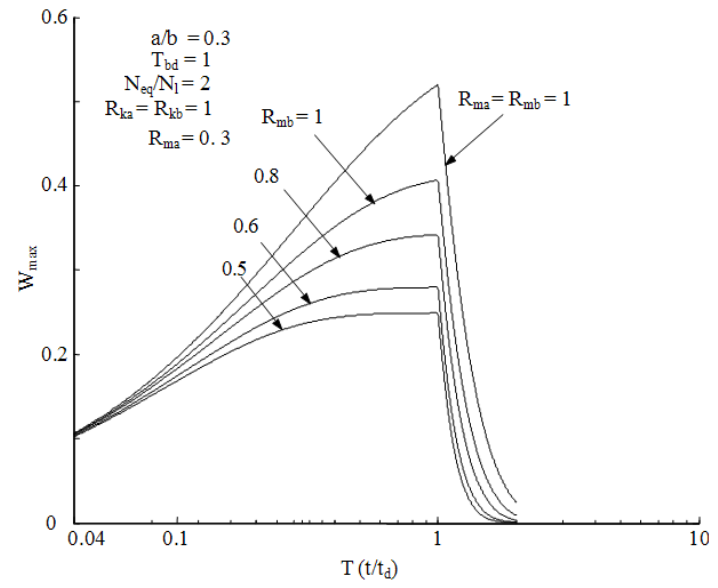

Fig. 12: Effect of $\mathrm{R}_{\mathrm{mb}}$ on $\mathrm{W}_{\max }{ }^{[64]}$

The modified form of the governing Eq. 1 with the inclusion effects of densification is:

$\frac{k_{h}(r)}{\gamma_{w} \cdot m_{v}(r)}\left(\frac{1}{r} \frac{\partial u}{\partial r}+\frac{\partial^{2} u}{\partial r^{2}}\right)+\frac{1}{\gamma_{w} \cdot m_{v}(r)} \cdot \frac{\partial\left(k_{h}(r)\right)}{\partial r} \cdot \frac{\partial u}{\partial r}=\frac{\partial u}{\partial t}-\frac{\partial u_{g}}{\partial N} \cdot \frac{\partial N}{\partial t}$

In this case coefficients of permeability, $\mathrm{k}_{\mathrm{h}}(\mathrm{r})$ and volume change, $\mathrm{m}_{\mathrm{v}}(\mathrm{r})$, are functions of radial distance, $r$, from the point of densification and degree of densification. Murali Krishna et $a l^{[64]}$ studied the densification effect with respect to the coefficients of permeability and volume change at the near and at the farthest ends of the granular pile, individually and together, on maximum pore pressure variations during an earthquake event. Figure 11 and 12 show the densification effect on maximum pore pressure ratio with respect to coefficient of volume change at the near and farthest ends respectively. $R_{m a}$ and $R_{m b}$ are normalized coefficients of volume change due to densification at the near and farthest ends respectively.

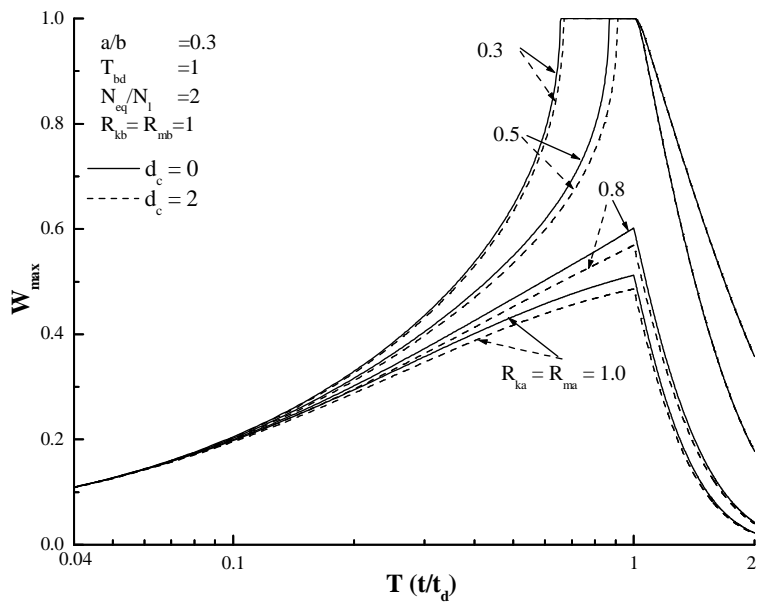

Fig. 13: Effect of densification with respect to $R_{k a}$ and $\mathrm{R}_{\mathrm{ma}}$ and dilation on $\mathrm{W}_{\max }{ }^{[66]}$

Murali Krishna and Madhav ${ }^{[66]}$ combined both the densification and dilation effects and incorporated them in the analysis of pore pressure generation and dissipation. They also verified the effect of variation of permeability with distance on maximum pore pressure ratios and concluded that the pore pressures ratios are not sensitive to the type of variation of permeability with distance. Figure 13 shows the effect of densification with respect to flow parameters at the near end in addition to the dilation effect. It is seen from the Fig. 13 that the dilation effect reduces the negative effect of reduced permeability.

\section{DISCUSSION}

Densification effect on the coefficient of volume change is positive in that the maximum induced pore water pressure ratios get reduced and sensitive to the type of variation considered as pore pressure ratios are lesser for the exponential variation compare to linear variation. Densification effect, on the coefficient of permeability alone or in addition to effect on coefficient of volume change, increases the maximum pore water pressure ratios giving a negative effect. The pore pressures ratios are not sensitive to the type of variation of permeability with distance. Densification effect on both coefficients of permeability and volume change result in a either slightly negative or positive effect depending on the degree of densification.

Further research is essential in the area of columnar granular inclusions as liquefaction countermeasure especially regarding encased granular columns. 


\section{CONCLUSION}

Liquefaction is the most disastrous feature during an earthquake that causes huge loss and damage to various structures founded on or in the ground. Ground improvements are extensively used to reinforce the in situ ground and also as liquefaction countermeasures. Columnar granular inclusions are the most widely used remedial measures against the liquefaction. Columnar granular inclusions provide drainage to mitigate the liquefaction potential of the ground. Various mechanisms such as reinforcement, densification, dilation along with the drainage mitigate the damages due to liquefaction. The study presents an over-view of the recent findings on the topic.

\section{REFERENCES}

1. Seed, H.B. and I.M. Idriss, 1982. Ground motions and soil liquefaction during earthquakes. EERI Publications, Oakland, California. http://openlibrary.org/b/OL3516119M/Groundmotions-and-soil-liquefaction-during-earthquakes

2. Mitchell, J.K. and F.K. Wentz, 1991. Performance of improved ground during Loma Prieta earthquake, Report No. EERC91/12, Earthquake Engineering Research Center, University of California, Berkeley. http://www.disg.uniroma1.it/biblioe/eerc.htm

3. Madhav, M.R. and K. Thiruselvam, 1988. Effect of Installation Methods on Granular Pile Response. Proc. Int. Symp. Theory and Practice of Earth Reinforcement, Kyushu, Japan, pp: 221-226. http://home.iitk.ac.in/ madhav/publications.htm

4. Seed, H.B. and J.R. Booker, 1977. Stabilization of potentially liquefiable sand deposits using gravel drains. J. Geotech. Eng. Divis. ASCE., 103: 757-768. http://ntlsearch.bts.gov/tris/record/tris/00165907.ht $\mathrm{ml}$

5. Terzaghi, K., 1925. Erdbaumechanik, Franz Deuticke, http://www.ejge.com/People/Terzaghi/Terzaghi.htm

6. Castro, G., 1969. Liquefaction of sands, Ph.D. Thesis, Harvard University, Cambridge, Massachusetts. http://books.google.co.in/books?id=iOlyGQAACA AJ

7. Casagrande, A., 1936. Characteristics of cohesionless soils affecting the stability of slopes and earth fills. J. Boston Soc. Civil Eng., 23: 13. http://books.google.co.in/books?id=5pZ_NwAAC AAJ
8. Seed, H.B. and K.L. Lee, 1966. Liquefaction of saturated sands during cyclic loading. J. Soil Mech. Foundat. Divis. ASCE., Proc., 92: 105-134. http://cedb.asce.org/cgi/WWWdisplay.cgi?6600291

9. Seed, H.B. and I.M. Idriss, 1971. Simplified procedure for evaluating soil liquefaction potential. J. Soil Mech. Foundat. Divis. ASCE., 97: 1249-1273. http://cedb.asce.org/cgi/WWWdisplay.cgi?7100947

10. Martin, G.R., W.D.L. Finn and H.B. Seed, 1975. Fundamentals of liquefaction under cyclic loading. J. Geotech. Eng. Divis. ASCE., 101: 425-438. http://cedb.asce.org/cgi/WWWdisplay.cgi?5011284

11. Seed, H.B., 1979. Soil liquefaction and cyclic mobility evaluation for level ground during earthquakes. J. Geotech. Eng. Divis. ASCE., 105: 201-255. http://cedb.asce.org/cgi/WWWdisplay.cgi?501438 0

12. Ishihara, K., 1993. Liquefaction and flow failure during earthquakes. Geotechnique, 42: 351-415. http://apps.isiknowledge.com/full_record.do?produ $\mathrm{ct}=$ WOS\&search $\_$mode $=$GeneralSearch \&qid $=5 \& \mathrm{~S}$ ID=Y156@GOD15fHponjfee\&page=1\&doc=2

13. Shibata, T., F. Oka and Y. Ozawa, 1996. Characteristics of ground deformation due to liquefaction. Special Issue on Soils and Foundations, pp: 65-79. http://cat.inist.fr/?aModele=afficheN\&cpsidt=2547461

14. Seed, R.B., K.O. Cetin, R.E.S. Moss, A.M. Kammerer, J. Wu, J.M. Pestana and M.F. Riemer, 2001. Recent advances in soil liquefaction engineering and seismic site response evaluation. Proc. 4th International Confernce Recent Advances in Geotechnical Earthquake Engineering and Soil Dynamics, San Diego, California, pp: 1-45. http://nisee.berkeley.edu/elibrary/Text/Lib050186

15. Youd, T.L., I.M. Idriss, D.A. Ronald, I. Arango, G. Castro, J.T. Christian, R. Dobry, W.D.L. Finn and L.F. Harder Jr. et al., 2001. Liquefaction resistance of soils: Summary report from the 1996 NCEER and 1998 NCEER/NSF workshops on evaluation of liquefaction resistance of soils. J. Geotech. Geoenviron. Eng., 124: 817-833. DOI: 10.1061/(ASCE)1090-0241(2001)127:10(817)

16. Dinesh, S.V., T.G. Sitharam and J.S. Vinod, 2004. Dynamic properties and liquefaction behavior of granular materials using discrete element method, Current Science special section. Geotech. Earthquake Hazards, 87: 1379-1387. http://www.ias.ac.in/currsci/nov252004/1379.pdf

17. Idriss, I.M. and R.W. Boulanger, 2005, Evaluation of liquefaction potential, consequences and mitigation. Proceeding of the Indian Geotechnical Conference, (IGC'05), Ahmedabad, India, pp: 3-25. http://scholar.google.co.in/scholar?hl=en\&lr=\&q= $\% 22$ Evaluation+of+Liquefaction+Potential $\% 2 \mathrm{C}+\mathrm{C}$ onsequences+and+Mitigation $\% 22 \& b \operatorname{bnG}=$ Search 
18. Sawicki, A. and J. Mierczynski, 2006, Developments in modeling liquefaction of granular soils, caused by cyclic loads. Applied Mech. Rev. Trans. $\quad$ ASME., 59: 91-106. DOI:10.1115/1.2130362

19. Sitharam, T.G. and J.S. Vinod, 2008, Numerical simulation of liquefaction and pore pressure generation in granular materials using DEM. Int. J. Geotech. Eng., 2: 103-113. DOI: 10.3328/IJGE.2008.02.02.103-113

20. Seed, H.B., P.P. Martin and M.J. Lysmer, 1976, Pore-water pressure changes during soil liquefaction. J. Geotech. Eng. Divis. ASCE., 102: 323-346. http://cedb.asce.org/cgi/WWWdisplay.cgi?5012074

21. Seed, H.B., K. Mori and C.K. Chan, 1977. Influence of seismic history on liquefaction of sands. J. Geotech. Eng. Divis. ASCE., 103: 257-270. http://cedb.asce.org/cgi/WWWdisplay.cgi?5012841

22. Hakuno, H. and Y. Tarumi, 1988. Sand liquefaction analysis by granular assembly simulation. Proceedings of Ninth World Conference on Earthquake Engineering, Tokyo, Japan, pp: 231-236. http://books.google.co.in/books?id=Si5SAAAAM AAJ\&pgis $=1$

23. Nakase, H., T. Takeda and M. Oda, 1999. A simulation study on liquefaction using DEM. In Seco e Pinto, editor, Earthquake Geotechnical Engineering, Rotterdam, Balkema, pp: 637-642. http://books.google.co.in/books?id=xp2TAAAAC AAJ

24. JGS., 1998. Remedial Measures against Soil Liquefaction. Ed. Japanese Geotechnical Society, Balkema, Rotterdam, Netherlands. http://books.google.co.in/books?id=4JRKHQAAC AAJ

25. PHRI, 1997. Handbook on liquefaction remediation of reclaimed land, Port and Harbor Research Institute, Editor, Balkema, Rotterdam, Netherlands. http://books.google.co.in/books?id=IOsbNPESEXgC

26. Yasuda, S., K. Ishihara, K. Harada and N. Shinkawa, 1996, Effect of soil improvement on ground subsidence due to liquefaction, soils and foundations. Special Issue on Geotech. Aspects January, 17, 1995 Hyogoken-Nambu Earthquake, pp: 99-107.

http://cat.inist.fr/?aModele $=$ afficheN\&cpsidt $=2544$ 913

27. Madabhushi, S.P.G., 2007. Ground improvement methods for liquefaction remediation. Ground Improv., 11: 195-206. DOI: 10.1680/grim.2007.11.4.195
28. Tsukamoto, Y., K. Ishihara, M. Yamamoto, K. Harada and H. Yabe, 2000, Soil densification due to static sand pile installation for liquefaction remediation. Soils Foundat., 40: 9-20. http://www.jiban.or.jp/e/sf/contents/40-2/40-22.html

29. Hughes, J.M.O. and N.J. Withers, 1974. Reinforcing of soft cohesive soils with stone columns. Ground Eng., 7: 42-49. http://scholar.google.co.in/scholar?hl=en \&lr=\&q= Reinforcing+of+Soft+Cohesive+Soils+with+Stone + Columns\&btnG $=$ Search

30. Hughes, J.M.O., N.J. Withers and D.A. Greenwood, 1975. A field trial of the reinforcing effect of a stone column in soil. Geotechnique, 25 : 31-44. http://www.engineeringvillage2.org/controller/serv let/Controller?SEARCHID=12d7d02121a72ad8e9 4db1prod1data1\&CID=quickSearchAbstractForma t\&DOCINDEX $=1 \&$ database $=3 \&$ format=quickSear chAbstractFormat

31. Datye, K.R. and S.S. Nagaraju, 1981, Design approach and field control for stone columns, Proceeding of the 10th International Conference on Soil Mechanics and Foundation Engineering, Stockholm, Sweden, 3, pp: 637-640. http://www.engineeringvillage2.org/controller/serv let/Controller?SEARCHID=58213c121a759f16b4d 59prod3data1\&CID=quickSearchAbstractFormat \& DOCINDEX $=1 \&$ database $=3 \&$ format=quickSearch AbstractFormat

32. Engelhardt, K. and H.C. Golding, 1975, Field Testing to evaluate stone column performance in a seismic area. Geotechnique, 25 : 61-69. http://www.engineeringvillage2.org/controller/serv let/Controller?SEARCHID=14d581b121a75fcb0d4 d70prod4data1\&CID=quickSearchAbstractFormat $\&$ DOCINDEX $=1 \&$ database $=3 \&$ format $=$ quickSear chAbstractFormat

33. Madhav, M.R., N.G.R. Iyengar, R.P. Vitkar and A. Nandia, 1979. Increased bearing capacity and reduced settlements due to inclusions in soil. Proceeding of International Conference on Soil Reinforcement: Reinforced Earth and Other Techniques, Paris, pp: 329-333. http://books.google.co.in/books?id=DvtRAAAAM AAJ\&pgis $=1$

34. Barksdale, R.D. and R.C. Bachus, 1983. Design and Construction of Stone Columns, Report No. FHWA/RD-83/026, US Department of Transportation, Federal Highway Administration, Washington, DC., USA. http://www.fhwa.dot.gov/engineering/geotech/libra ry_arc.cfm?pub_number $=28$ 
35. Balaam, N.P. and J.R. Booker, 1981. Analysis of rigid raft supported by granular piles. Int. J. Num. Anal. Methods Geomech., 5: 379-403. DOI: 10.1002/nag.1610050405

36. Datye, K.R. and S.S. Nagaraju, 1975, Installation and testing of rammed stone columns, Proceeding of the IGS Specialty Session, 5th Asian Regional Conference on SMFE, Bangalore, India, pp: 101-104. http://books.google.co.in/books?id=cDGIhh7ttMc $\mathrm{C} \& \mathrm{pg}=\mathrm{PA} 255 \& \mathrm{lpg}=\mathrm{PA} 255 \& \mathrm{dq}=\% 22$ Installation + and+testing+of+rammed+stone+columns $\% 22 \&$ sou rce=bl\&ots=JPAaMOGSCB \&sig=BNP136JMauYy iN9ALpFGZo7foMA\&hl=en\&ei=0xkyStH6JNCks AbM38SjCQ\&sa=X\&oi=book_result\&ct=result\&r esnum $=3$

37. Raithel, M., H.G. Kempfert and A. Kirchner, 2002. Geotextile-Encased Columns (GEC) for foundation of a dike on very soft soils. Proceedings of the 7th International Conference on Geosynthetics. A.A. Balkema Publishers, Nice, France, pp: 1025-1028. http://www.kup-

geotechnik.de/kup/Veroeffentlichungen/2002/2002 _Raithel_7.ICGNizza.pdf

38. Raithel, M., A. Kirchner, C. Schade and E. Leusink, 2005. Foundation of constructions on very soft soils with geotextile encased columns-State of the art. Geotechnical Special Publication, No. 130-142, Geo-Frontiers 2005, 1867-1877. http://cedb.asce.org/cgi/WWWdisplay.cgi?0500484

39. Malarvizhi, S.N. and K. Ilamparuthi, 2006, Behavior of geogrid encased stone column and stone column stabilized soft clay bed, Proceeding of the 6th International Conference on Physical Modeling in Geotechnics, pp: 1489-1494. http://books.google.co.in/books?id=mzQlFBqJC1wC

40. Murugesan, S., K. Rajagopal, 2006, Geosyntheticencased stone columns: Numerical evaluation. Geotextiles Geomembrane., 24: 349-358. DOI:10.1016/j.geotexmem.2006.05.001

41. Murugesan, S. and K. Rajagopal, 2007, Model tests on geosynthetic encased stone columns. Geosynthet. Int., 24: 349-358. DOI: 10.1680/gein.2007.14.6.346

42. Wu, C.S. and Y.S. Hong, 2008. Laboratory tests on geosynthetic-encapsulated sand columns. Geotextiles Geomembrane., 27: 107-120. DOI: 10.1016/j.geotexmem.2008.09.003

43. Munfakh, G.A., L.W. Abramson, R.D. Barksdale and I. Juran, 1987. In situ ground reinforcement. Proceeding of the Soil Improvement-A Ten Year Update, Geotechnical Special Publication No. 12, ASCE., pp: 1-17. http://cedb.asce.org/cgi/WWWdisplay.cgi?8700746
44. Baez, J.I. and G.R. Martin, 1992. Quantitative evaluation of stone column technique for earthquake liquefaction mitigation. Proceeding of 10th World Conference on Earthquake Engineering, $\quad$ pp: 1477-1483. http://books.google.co.in/books?id=KQEggXhSdJo C

45. Lopez, R.A. and R.F. Hayden, 1992. The use of vibro systems in seismic design. Grouting. Soil Improvement and Geosynthetics, Borden, R.H., R.D. Holtz and I. Juran (Eds.). ASCE Geotechnical Special Publication No. 30, 2, pp:1433-1445. http://cedb.asce.org/cgi/WWWdisplay.cgi?9200496

46. Brennan, A.J. and S.P.G. Madabhushi, 2002. Effectiveness of vertical drains in mitigation of liquefaction. Soil Dyn. Earthquake Eng., 22: 1059-1065. DOI: 10.1016/S0267-7261(02)00131-8

47. Al-Homoud, A.S. and W.S. Degen, 2006. Marine stone columns to prevent earthquake induced soil liquefaction. Geotech. Geol. Eng., 24: 775-790. DOI: $10.1007 / \mathrm{s} 10706-005-2783-5$

48. Adalier, K. and A. Elgamal, 2004. Mitigation of liquefaction and associated ground deformations by stone columns. Eng. Geol., 72: 275-291. DOI: 10.1016/j.enggeo.2003.11.001

49. Sasaki, Y. and E. Taniguchi, 1982. Shaking table tests on gravel drains to prevent liquefaction of sand deposits. Soils Foundat., 22: 1-14. http://ci.nii.ac.jp/vol_issue/nels/AN00173174/ISS0 000245604_en.html

50. Adalier, K., A. Elgamal, J. Meneses and J.I. Baez, 2003. Stone columns as liquefaction countermeasure in non-plastic silty soils. Soil Dyn. Earthquake Eng., 23: 571-584. DOI: 10.1016/S0267-7261(03)00070-8

51. Ohbayashi, J., K. Harada and M. Yamamoto, 1999. Resistance against liquefaction of ground improved by sand compaction pile method. Earthquake Geotechnical Engineering, Seco e Pinto (Ed.). Balkama, Rotterdam, pp: 549-554. http://www.amazon.co.uk/Earthquake-GeotechnicalEngineering-Proceedings-International/dp/9058091163

52. Okamura, M., M. Ishihara and T. Oshita, 2003. Liquefaction resistance of sand improved with sand compaction piles. Soils Foundat., 43: 175-187. http://ci.nii.ac.jp/vol_issue/nels/AN10496056/ISS0 000242976_en.html

53. Chang, W.J., E.M. Rathje, K.H. Stokoe II. and B.R. Cox, 2004. Direct evaluation of effectiveness of prefabricated vertical drains in liquefiable sand. Soil Dyn. Earthquake Eng., 24: 723-731. DOI: 10.1016/j.soildyn.2004.06.007 
54. Iai, S., K. Koizumi, S. Noda and H. Tsuchida, 1988. Large scale model tests and analysis of gravel drains. Proc., 9th World Conference on Earthquake. Eng., Tokyo-Kyoto, Japan, 3. http://scholar.google.co.in/scholar?hl=en\&lr=\&q= $\% 22$ Large+scale+model+tests+and+analysis + of $+g$ ravel+drains \%22\&btnG=Search

55. Sadrekarimi, A. and A. Ghalandarzadeh, 2005. Evaluation of gravel drains and compacted sand piles in mitigating liquefaction. Ground Improv., 9: 91-104. DOI: 10.1680/grim.2005.9.3.91

56. Seed, H.B., I.M. Idriss, F. Makdisi and N. Bannerjee, 1975. Representation of irregular stress time histories by equivalent uniform stress series in liquefaction analyses, Report No. UCB/EERC/7529, Earthquake Engineering Research Center, University of California, Berkeley, California. http://nisee.berkeley.edu/documents/EERC/EERC75-29.pdf

57. Tokimatsu, K. and Y. Yoshimi, 1980, Effects of vertical drains on the bearing capacity of saturated sand during earthquakes. Proc., International Conference on Engineering for Protection from Natural Disasters, Bangkok, Thailand, pp: 643-655. http://www.arch.titech.ac.jp/tokimatsu/publications /conf_papers.htm

58. Onoue, A., 1988. Diagrams considering well resistance for designing spacing ratio of gravel drains. Soils Foundat., 28: 160-168. http://ci.nii.ac.jp/vol_issue/nels/AN00173174/ISS0 000243864_en.html

59. Pestana, J.M., C.E. Hunt and R.R. Goughnour, 1997. FEQDrain: A finite element computer program for the analysis of the earthquake generation and dissipation of pore water pressure in layered sand deposits with vertical drains, Report No.

UCB/EERC-97-15. http://nisee.berkeley.edu/documents/EERC/EERC97-15.pdf

60. Pestana, J.M., C.E. Hunt, R.R. Goughnour and A.M. Kammerer, 1998. Effect of storage capacity on vertical drain performance in liquefiable sand deposits. Proc. Second International Conference on Ground Improvement Techniques, Singapore, pp: 373-380.

http://citeseerx.ist.psu.edu/viewdoc/summary?doi= 10.1.1.17.9949
61. Poorooshasb, H.B., A. Noorzad, N. Miura and M.R. Madhav, 2000. Prevention of earthquake induced liquefaction of sandy deposits using stone columns. Proc. Int. Symp. on Lowland Technology, Saga, pp: 213-220. http://home.iitk.ac.in/ madhav/publications.htm

62. Madhav, M.R. and J.N. Arlekar, 2000. Dilation of granular piles in mitigating liquefaction of sand deposits. Proceeding 12th World Conference Earthquake Engineering, Auckland, No: 1035 (CDROM). http://d.wanfangdata.com.cn/NSTLHY_NSTL_HY 2141666.aspx

63. Murali Krishna, A. and M.R. Madhav, 2007. Equivalent deformation properties of ground treated with rammed granular piles. Int. J. Geotech. Eng., 1: 31-38. DOI: 10.3328/IJGE.2007.01.01.3138

64. Murali Krishna, A., M.R. Madhav and G. Madhavi Latha, 2006. Liquefaction mitigation of ground treated with granular piles: Densification effect. ISET J. Earthquake Technol., 43: 105-120. http://home.iitk.ac.in/ vinaykg/issue21.html

65. Murali Krishna, A., M.R. Madhav and G. Madhavi Latha, 2007. Densification effect of granular piles on settlement response of treated ground. Ground Improv., $\quad 11$ : 127-136. DOI:10.1680/grim.2007.11.3.127

66. Murali Krishna, A. and M. R. Madhav, 2008. Densification and dilation effects of granular piles in liquefaction mitigation. Indian Geotech. J., 38: 295-316. http://www.igschennai.in/parent/abstracts/jul2008. pdf 